\title{
Uneven growth and different susceptibility to viruses among bacteria increase estimates of virus production in the East Sea based on TEM observation
}

\author{
Chung Y. Hwang, Byung C. Cho* \\ School of Earth and Environmental Sciences and Research Institute of Oceanography, Seoul National University, \\ Seoul 151-742, Republic of Korea
}

\begin{abstract}
We developed a theory that uneven distribution of bacterial growth rates and different susceptibility to viral infection in bacterial community could result in higher estimates of virus production based on transmission electron microscopy (TEM) observation ( $V P_{\text {TEM }}$ ) compared to estimates obtained by neglecting uneven growth and different susceptibilities in the bacterial community. We tested this idea by classifying bacteria into 4 groups based on morphotypes (i.e. rods, cocci, curved shapes, and spirillae) and enumerating the frequency of visibly infected cells (FVIC) and the frequency of dividing cells (FDC; an indirect measure of the growth rates) in the 4 groups in the East Sea samples $(n=15)$. FVIC and FDC varied between different morphotypes and were highest in cocci. Further, FVIC and estimated growth rates of bacterial morphotypes were significantly correlated. The presence of a fast-growing bacterial group (apparently more susceptible to viral infection) in the bacterial community substantially increased (1.2 to 2.8 -fold) the estimates of $V P_{\text {TEM }}$ in comparison to those obtained by using the mean growth rate of the bacterial community. Until now the differences between virus production measured by virus decay rates $\left(V P_{\mathrm{D}}\right)$ and $V P_{\mathrm{TEM}}$ have been thought to be explained by adsorption of viruses to particles, degradation of viruses due to enzymes and inactivation of viruses caused by sunlight. It seems that uneven growth and different susceptibility to viruses in the bacterial community might be another additional explanation for the discrepancy between $V P_{\mathrm{D}}$ and $V P_{\mathrm{TEM}}$.
\end{abstract}

KEY WORDS: Virus production · Transmission electron microscopy · Uneven growth · Different susceptibility to viral infection

\section{INTRODUCTION}

Virus production is an important biological variable that can be used to estimate both the bacterial mortality due to viral lysis and the turnover rate of viruses in aquatic ecosystems. Several methods for determining virus production have been developed and applied to field samples. Generally, 4 kinds of methods have been used to estimate virus production. The first method is used to measure decay rates of viruses where viral production has been halted by adding cyanide ( $V P_{\mathrm{D} i}$ Heldal \& Bratbak 1991). The second method of determining virus production is used to measure incorporation rates of radiolabelled phosphate or thymidine tracers

*Corresponding author. E-mail: bccho@plaza.snu.ac.kr in viral nucleic acid (Steward et al. 1992, Fuhrman \& Noble 1995). The third method involves the use of fluorescently labeled viruses as tracers for determining the rates of production and removal (Noble \& Fuhrman 2000). The fourth method is used to enumerate the frequency of visibly infected cells by transmission electron microscopy (TEM) observation. Then, total bacterial production and burst size are combined to calculate virus production ( $V P_{\mathrm{TEM}}$ G Guixa-Boixareu et al. 1996, Steward et al. 1996).

Recently, Pinhassi et al. (1999) reported that the growth rate of single bacterial species was 5 times faster than the community growth rate and occupied ca. $22 \%$ of bacterial abundance. It is also shown that the specific growth rates of different morphological groups in the natural bacterial community are different 
and changeable in a day (Turley \& Lochte 1986). Considering that the impact of phages on bacteria strongly depends on the metabolic activity of the host (Weinbauer \& Peduzzi 1994), virus production rates could vary depending on the growth rates of bacterial groups. Thus, we reasoned that estimates of $V P_{\text {TEM }}$ might increase with assumptions of an uneven distribution of bacterial growth rates and different susceptibility to viral infection in bacterial community compared to those obtained by mean bacterial growth rate and identical susceptibility to viruses in the bacterial community. In this study, we developed a theoretical model and applied it to the field samples. We compared the frequencies of visibly infected cells (FVIC) and the frequencies of dividing cells (FDC) among different bacterial morphotypes in samples from the East Sea. The presence of fast-growing bacteria (apparently more susceptible to virus infection) in the bacterial community substantially increased the estimates of $V P_{\text {TEM }}$.

\section{MATERIALS AND METHODS}

Study area. Samples were collected between October 12 and 17, 1999, in the East Sea, Korea. Three offshore sites (A2: $129^{\circ} 45^{\prime} \mathrm{E}, 37^{\circ} 45^{\prime} \mathrm{N}$; A3: $130^{\circ} 21^{\prime} \mathrm{E}$, $37^{\circ} 53^{\prime} \mathrm{N}$; $\mathrm{A} 4: 130^{\circ} 58^{\prime} \mathrm{E}, 37^{\circ} 50^{\prime} \mathrm{N}$ ) were visited, and the sampling depths for each site corresponded to standard depths (i.e. 0, 10, 20, 30 and $50 \mathrm{~m}$ ).

Bacterial production. Bacterial production was measured by the ${ }^{14} \mathrm{C}$-leucine incorporation method (Simon \& Azam 1989). Ten to $30 \mathrm{ml}$ of seawater samples in triplicate were dispensed to sterile polypropylene tubes, and ${ }^{14} \mathrm{C}$-leucine (specific activity $=304 \mathrm{mCi}$ $\mathrm{mmol}^{-1}$ ) was added to each tube at $10 \mathrm{nM}$ (final conc.). Formalin-killed samples (final conc. of $2 \%$ ) served as blanks. The samples were incubated in the dark at in situ temperature for less than $2 \mathrm{~h}$. The incorporated radioactivity was converted to cell number produced using a conversion factor of $0.18 \times 10^{18} \mathrm{cells} \mathrm{mol}^{-1}$ leucine incorporated (Ducklow et al. 1992, Cho et al. 2000).

Virus production based on TEM observation ( $\boldsymbol{V} \boldsymbol{P}_{\text {TEM }}$ ). Samples for measurement of virus production were preserved with electron-microscopy-grade glutaraldehyde (final conc. of $2 \%$ ) and stored in sterile polypropylene centrifuge tubes at $4^{\circ} \mathrm{C}$. Other steps were performed as in Weinbauer \& Suttle (1997), except for the centrifugation speed. To collect bacteria on grids, samples (5 ml) were centrifuged (Beckman $\mathrm{XL}-90)$ at $15000 \mathrm{rpm}(30000 \times g)$ using a swinging bucket rotor (SW41) for $30 \mathrm{~min}$ at $20^{\circ} \mathrm{C}$. Cells were harvested directly onto Formvar-coated, 200-mesh electron-microscope grids that were made evenly hydrophilic by floating on a drop of $1 \%$ poly-L-Lysine for $1 \mathrm{~min}$ (Suttle 1993). Grids were stained for $20 \mathrm{~s}$ with $0.5 \%$ uranyl acetate followed by 3 sequential rinses with $0.02 \mu \mathrm{m}$ filtered Milli- $\mathrm{Q}^{\circledR}$ water. We examined more than 300 bacteria per sample using a TEM (JEOL 2000 EXII) operated at $100 \mathrm{keV}$ and at $30000 \times$ magnification. Bacteria were classified into 4 groups based on morphotypes (i.e. rods, cocci, curved shapes and spirillae). Relative abundance, FVIC and FDC were measured for each morphotype by TEM observation. We used a conversion factor of 5.42 to convert FVIC to frequency of infected cells (FIC; Proctor et al. 1993). $V P_{\text {TEM }}$ was calculated by multiplying together burst size, FIC and bacterial production (Guixa-Boixareu et al. 1996, Steward et al. 1996).

Other analyses. Regression analysis and analysis of variance (ANOVA) were carried out using SPSS for Windows (Ver. 8.0, SPSS Inc. 1997). Numerical simulations of models in this paper were performed using Fortran PowerStation (Ver. 4.0, Microsoft Corp. 1994) for Windows 98.

\section{RESULTS AND DISCUSSION}

\section{Model development}

To start with the simplest model, we used a hypothetical bacterial community composed of 2 groups. One group is growing faster and the other group growing slower than mean growth rate of the total bacterial community. First, we can demonstrate that the frequency of infected cells in the slow-growing group, $F I C_{\mathrm{s}}$, can be expressed in terms of variables of the fastgrowing group (symbols summarized in Table 1):

$$
\begin{gathered}
\frac{\rho_{\mathrm{f}}}{\delta_{\mathrm{f}}}=\frac{N_{\mathrm{f}} / N_{\mathrm{T}}}{I_{\mathrm{f}} / I_{\mathrm{T}}}=\frac{I_{\mathrm{T}}}{N_{\mathrm{T}}} \times \frac{1}{I_{\mathrm{f}} / N_{\mathrm{f}}}=F I C_{\mathrm{T}} \times \frac{1}{F I C_{\mathrm{f}}} \\
F I C_{\mathrm{T}}=\frac{\rho_{\mathrm{f}}}{\delta_{\mathrm{f}}} \times F I C_{\mathrm{f}}
\end{gathered}
$$$$
F I C_{\mathrm{s}}=\frac{I_{\mathrm{s}}}{N_{\mathrm{s}}}=\frac{I_{\mathrm{T}}-I_{\mathrm{f}}}{N_{\mathrm{T}}-N_{\mathrm{f}}}=\frac{I_{\mathrm{T}}}{N_{\mathrm{T}}} \times \frac{1-I_{\mathrm{f}} / I_{\mathrm{T}}}{1-N_{\mathrm{f}} / N_{\mathrm{T}}}=F I C_{\mathrm{T}} \times \frac{1-\delta_{\mathrm{f}}}{1-\rho_{\mathrm{f}}}
$$

From Eq. (1),

$$
F I C_{\mathrm{s}}=\frac{\rho_{\mathrm{f}}\left(1-\delta_{\mathrm{f}}\right)}{\delta_{\mathrm{f}}\left(1-\rho_{\mathrm{f}}\right)} \times F I C_{\mathrm{f}}
$$

Assuming that the latent period is approximately equal to the generation time of bacteria (Proctor et al. 1993, Guixa-Boixareu et al. 1996), and the infected cells are removed only by viral lysis, virus production can be calculated by (Guixa-Boixareu et al. 1996, Steward et al. 1996): 
Table 1. Abbreviations used in the text. Units are indicated in parentheses, otherwise dimensionless

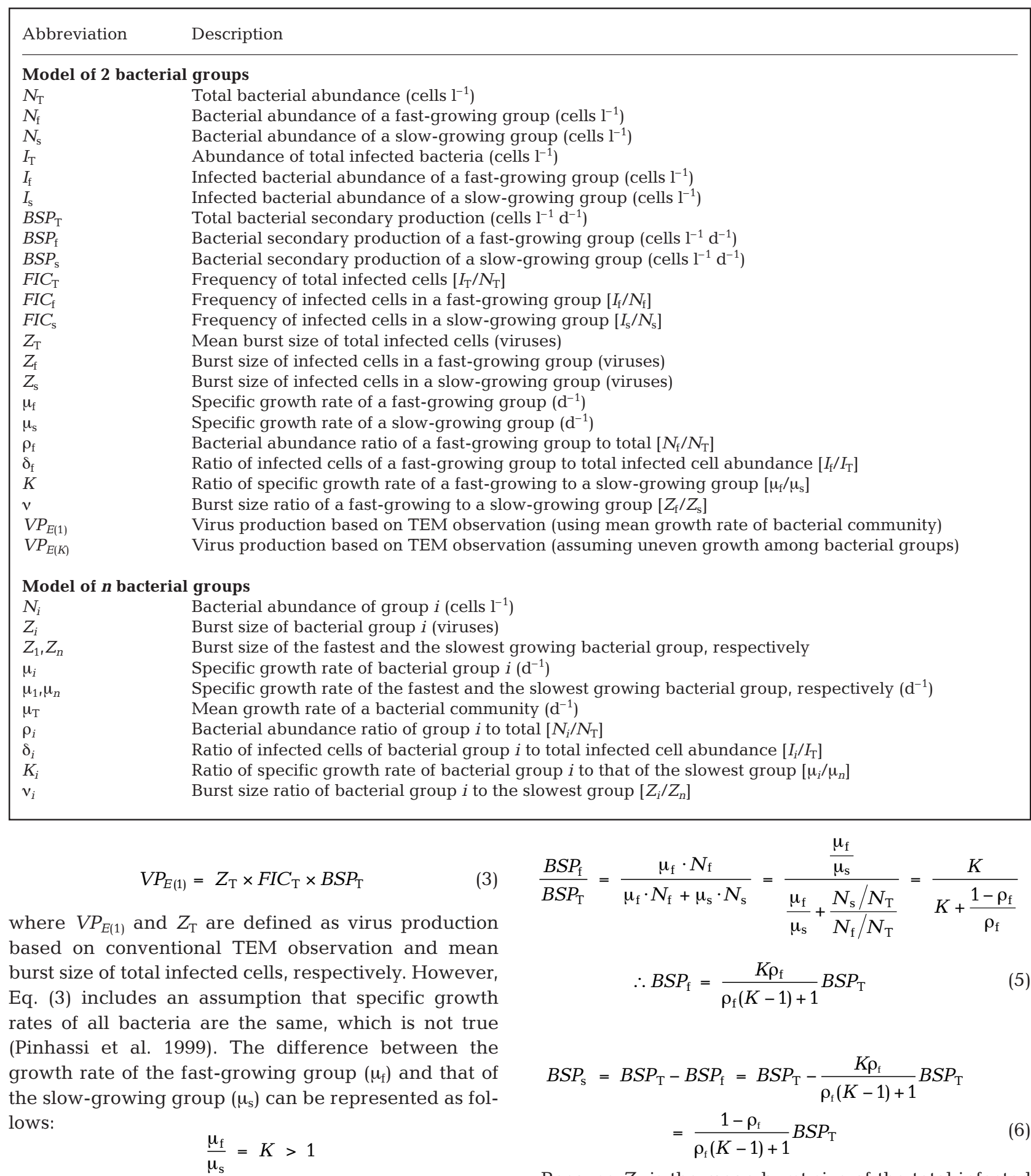

Bacterial secondary production $(B S P)$ is equal to the multiplication of the specific growth rate $(\mu)$ and the bacterial abundance ( $N$; Pollard \& Moriarty 1984), and the total $B S P$ is the sum of the bacterial production of fast- and slow-growing groups. Therefore:

$$
B S P_{\mathrm{T}}=B S P_{\mathrm{f}}+B S P_{\mathrm{S}}
$$

Because $Z_{\mathrm{T}}$ is the mean burst size of the total infected cells, $Z_{\mathrm{T}}$ can be represented by the burst size of fast$\left(Z_{\mathrm{f}}\right)$ and slow-growing $\left(Z_{\mathrm{s}}\right)$ bacterial groups:

$$
Z_{\mathrm{T}}=\delta_{\mathrm{f}} Z_{\mathrm{f}}+\left(1-\delta_{\mathrm{f}}\right) Z_{\mathrm{s}}
$$

Further, to simplify equations, a parameter $(v)$ is introduced as the ratio of $Z_{\mathrm{f}}$ to $Z_{\mathrm{s}}$. 
Since total virus production is a sum of virus production of 2 bacterial groups, we obtain:

$$
V P_{E(K)}=V P_{\mathrm{f}}+V P_{\mathrm{s}}=Z_{\mathrm{f}} \times F I C_{\mathrm{f}} \times B S P_{\mathrm{f}}+Z_{\mathrm{s}} \times F I C_{\mathrm{s}} \times B S P_{\mathrm{s}}
$$

Substituting Eqs. (2), (5) \& (6) into Eq. (8), we obtain:

$$
V P_{E(K)}=\left(Z_{\mathrm{s}} \frac{1-\delta_{\mathrm{f}}}{\delta_{\mathrm{f}}}+K Z_{\mathrm{f}}\right) \times \frac{\rho_{\mathrm{f}}}{\rho_{\mathrm{f}}(K-1)+1} \times F I C_{\mathrm{f}} \times B S P_{\mathrm{T}}
$$

If $K$ is equal to 1 (i.e. growth rates of 2 bacterial groups are the same) and there is no significant difference in burst size between the 2 groups (i.e. $v=1$ ), we obtain:

$$
V P_{E(1)}=Z_{\mathrm{T}} \times \frac{\rho_{\mathrm{f}}}{\delta_{\mathrm{f}}} \times F I C_{\mathrm{f}} \times B S P_{\mathrm{T}}
$$

which is exactly the same as Eq. (3) used routinely for calculating $V P_{\mathrm{TEM}}$.

Combining Eqs (9) \& (10), we obtain:

$$
\frac{V P_{E(K)}}{V P_{E(1)}}=\frac{\delta_{\mathrm{f}}(v K-1)+1}{\left[\rho_{\mathrm{f}}(K-1)+1\right] \cdot\left[\delta_{\mathrm{f}}(v-1)+1\right]}
$$

For $v=1$, we have:

$$
\frac{V P_{E(K)}}{V P_{E(1)}}=\frac{\delta_{\mathrm{f}}(K-1)+1}{\rho_{\mathrm{f}}(K-1)+1}
$$

Eq. (12) indicates that if $\delta_{\mathrm{f}}>\rho_{\mathrm{f}}$ (i.e. virus infection is biased to a fast-growing bacterial group), $V P_{E(K)}$ would always be higher than $V P_{E(1)}$ since $K>1$. In contrast, if $\delta_{\mathrm{f}}<\rho_{\mathrm{f}}, V P_{E(K)}$ is lower than $V P_{E(1)}$. This case, however, would be implausible in natural environments because slow-growing bacteria must be more infected than fast-growing ones. If fast-growing bacteria have a larger burst size and are more infected than slowgrowing ones, for the given values of $\delta_{\mathrm{f}}, \rho_{\mathrm{f}}$ and $K$, the ratios of $V P_{E(K)}$ to $V P_{E(1)}$ of Eq. (11) become larger than those obtained for the case where $v=1$ (data not shown). But if fast-growing bacteria have a smaller burst size than slow-growing bacteria $(v<1)$, in all cases the ratios will be smaller than 1 , whether $\delta_{\mathrm{f}}$ is larger than $\rho_{\mathrm{f}}$ or not (data not shown).

Further, we can mathematically demonstrate that Eq. (11) can be expanded for a bacterial community composed of $n$ groups. For a bacterial community consisting of $n$ bacterial groups, it could be possible to rearrange bacterial groups in a descending order in terms of growth rates $\left(\mu_{i} \geq \mu_{i+1} ; \mu_{1}\right.$ and $\mu_{n}$ are the growth rates of the fastest-growing and slowest-growing bacteria, respectively). We define $K_{i}$ and $v_{i}$ as the ratio of $\mu_{i}$ to $\mu_{n}$ and $Z_{i}$ to $Z_{n}$, respectively. Considering different growth and uneven susceptibility to viruses, virus production $\left(V P_{E(K)}\right)$ will be:

$$
\begin{aligned}
& V P_{E(K)}=Z_{1} \times F I C_{1} \times N_{1} \times \mu_{1}+ \\
& Z_{2} \times F I C_{2} \times N_{2} \times \mu_{2}+\cdots+Z_{n} \times F I C_{n} \times N_{n} \times \mu_{n}
\end{aligned}
$$

From $F I C_{i}=\frac{\delta_{i}}{\rho_{i}} F I C_{\mathrm{T}}$ (see Eq. 1), we obtain:

$$
\begin{aligned}
V P_{E(K)} & =Z_{1} \times \frac{\delta_{1}}{\rho_{1}} F I C_{\mathrm{T}} \times \rho_{1} \times N_{\mathrm{T}} \times \mu_{1}+Z_{2} \times \frac{\delta_{2}}{\rho_{2}} F I C_{\mathrm{T}} \\
& \times \rho_{2} \times N_{\mathrm{T}} \times \mu_{2}+\cdots+Z_{n} \times \frac{\delta_{n}}{\rho_{n}} F I C_{\mathrm{T}} \times \rho_{n} \times N_{\mathrm{T}} \times \mu_{n} \\
& =F I C_{\mathrm{T}} \times N_{\mathrm{T}} \times \sum_{i=1}^{n} Z_{i} \mu_{i} \delta_{i}
\end{aligned}
$$

Further, since $B S P_{\mathrm{T}}=N_{\mathrm{T}} \mu_{\mathrm{T}}=N_{\mathrm{T}} \sum_{i=1}^{n} \mu_{i} \rho_{i}$ and $Z_{\mathrm{T}}=\sum_{i=1}^{n} Z_{i} \delta_{i}$ Eq. (3) can be changed to:

$$
\begin{aligned}
V P_{E(1)} & =Z_{\mathrm{T}} \times F I C_{\mathrm{T}} \times N_{\mathrm{T}} \times \mu_{\mathrm{T}} \\
& =\sum_{i=1}^{n} Z_{i} \delta_{i} \times F I C_{\mathrm{T}} \times N_{\mathrm{T}} \times \sum_{i=1}^{n} \mu_{i} \rho_{i}
\end{aligned}
$$

Thus, we obtain:

$$
\begin{aligned}
& \frac{V P_{E(K)}}{V P_{E(1)}}=\frac{\sum_{i=1}^{n} Z_{i} \mu_{i} \delta_{i}}{\sum_{i=1}^{n} Z_{i} \delta_{i} \times \sum_{i=1}^{n} \mu_{i} \rho_{i}} \\
& =\frac{Z_{1} \mu_{1} \delta_{1}+Z_{2} \mu_{2} \delta_{2}+\cdots+Z_{n} \mu_{n} \delta_{n}}{\left(\delta_{1} Z_{1}+\delta_{2} Z_{2}+\cdots+\delta_{n} Z_{n}\right)\left(\mu_{1} \rho_{1}+\mu_{2} \rho_{2}+\cdots+\mu_{n} \rho_{n}\right)}
\end{aligned}
$$

Dividing both the numerator and the denominator by $Z_{\mathrm{n}} \mu_{\mathrm{n}}$, then $V P_{E(K)} / V P_{E(1)}$ can be modified with respect to $K_{i}$ and $v_{i}$ :

$\frac{V P_{E(K)}}{V P_{E(1)}}=$

$\frac{v_{1} K_{1} \delta_{1}+v_{2} K_{2} \delta_{2}+\cdots+v_{n-1} K_{n-1} \delta_{n-1}+\delta_{n}}{\left(\delta_{1} v_{1}+\delta_{2} v_{2}+\cdots+\delta_{n-1} v_{n-1}+\delta_{n}\right)\left(K_{1} \rho_{1}+K_{2} \rho_{2}+\cdots+K_{n-1} \rho_{n-1}+\rho_{n}\right)}$

From the definition:

$$
\begin{array}{ll}
\sum_{i=1}^{n} \delta_{i}=1, & \delta_{n}=1-\left(\delta_{1}+\delta_{2}+\cdots+\delta_{n-1}\right) \\
\sum_{i=1}^{n} \rho_{i}=1, & \rho_{n}=1-\left(\rho_{1}+\rho_{2}+\cdots+\rho_{n-1}\right)
\end{array}
$$

Insertion of $\delta_{n}$ and $\rho_{n}$ into Eq. (16) gives the following:

$$
\frac{V P_{E(K)}}{V P_{E(1)}}=\frac{1+\sum_{i=1}^{n-1} \delta_{i}\left(v_{i} K_{i}-1\right)}{\left(1+\sum_{i=1}^{n-1} \delta_{i}\left(v_{i}-1\right)\right)\left(1+\sum_{i=1}^{n-1} \rho_{i}\left(K_{i}-1\right)\right)}
$$

For $v_{i}=1$ (i.e. same burst size in each group), Eq. (17) becomes:

$$
\frac{V P_{E(K)}}{V P_{E(1)}}=\frac{1+\sum_{i=1}^{n-1} \delta_{i}\left(K_{i}-1\right)}{1+\sum_{i=1}^{n-1} \rho_{i}\left(K_{i}-1\right)}
$$




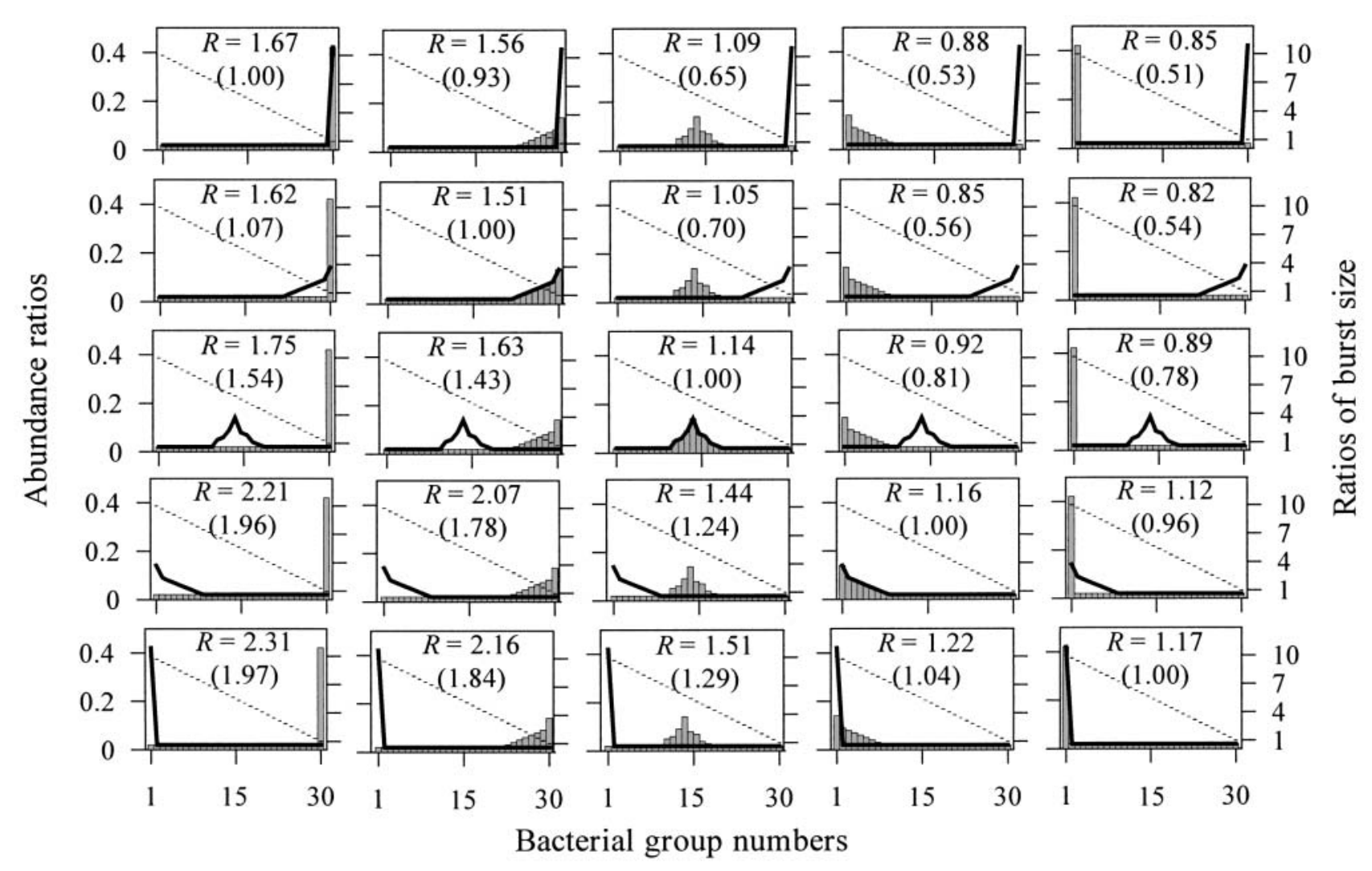

Fig. 1. A typical example of the numerical simulation analyses of our model. Bacterial groups $(n=30)$ in a hypothetical community were evenly arranged in descending order in terms of growth rate (i.e. $\left.\mu_{1} / \mu_{30}=10\right)$. In each panel, the $R$-value $(=$ $\left.V P_{E(K)} / V P_{E(1)}\right)$ without parentheses was calculated assuming a linear increase in burst size with growth rate (dotted line); the $R$ value in parentheses was calculated assuming a constant burst size among bacterial groups. Solid lines represent distributions of $\delta_{i}$ among bacterial groups, and vertical bars $\rho_{i} . \rho_{i}, \delta_{i} \in[0.02,0.42]$. For definitions of symbols, see Table 1

which is similar in form to Eq. (12) obtained for the 2bacterial-group model.

As seen for the 2-bacterial-group model, similar results are obtained for a case of 30 bacterial groups (Fig. 1) as well as 10 and 100 bacterial groups (data not shown). Assuming that virus infection is biased to fast-growing bacterial groups, numerical simulation analyses show that the ratios of $V P_{E(K)}$ to $V P_{E(1)}$ are greater than 1. Further, inclusion of a very slow growing bacterial group in a bacterial community (e.g. $0.001 \mathrm{~d}^{-1}$, leading to an extremely high value of $K_{1}$ ) gives a similar result $\left(V P_{E(K)} / V P_{E(1)}>1\right.$, data not shown). Consideration of an active but non-dividing bacterial group in the community requires a slight modification of Eq. (15) for numerical simulation analysis. The results of the analyses show that the ratios of $V P_{E(K)}$ to $V P_{E(1)}$ are still higher than 1 when virus infection is biased to fast-growing bacterial groups (data not shown). There are cases in which the ratios of $V P_{E(K)}$ to $V P_{E(1)}$ are lower than 1 (Fig. 1). These cases are possible when an ecologically irrelevant assumption is made (i.e. slow-growing bacteria are more infected than fast-growing ones). If fast-growing bacteria have a larger burst size and are more infected than slowgrowing ones (Fig. 1), for the given values of $\delta_{\mathrm{f}}, \rho_{\mathrm{f}}$ and $K$, the ratios of $V P_{E(K)}$ to $V P_{E(1)}$ of Eq. (17) become larger than those obtained for a case of $v=1$ (see Fig. 1). But, if fast-growing bacteria have a smaller burst size than slow-growing bacteria $(v<1)$, the ratios generally tend to be smaller than those obtained for a case of $v=1$ (data not shown). Weinbauer \& Peduzzi (1994) reported that burst sizes correlated positively with cell size. In general, more actively growing bacteria are larger than slowly growing bacteria (Gasol et al. 1995). Thus, intuitively, a positive relationship between growth rates and burst sizes would be expected for natural marine bacteria. In a numerical simulation of our model, a positive relationship between growth rates and burst sizes was assumed for cases where $v>$ 1 (Fig. 1). Neither the use of an exponential nor a sigmoidal relationship between growth rates and burst sizes substantially increases the ratios of $V P_{E(K)}$ to $V P_{E(1)}$ of Eq. (17) (data not shown). Overall, our model predicts that with an ecologically relevant assumption, the estimated virus production would be generally upward. 
Table 2. Relative abundance and frequency of visibly infected cells (FVIC) in various bacterial morphotypes in some marine environments. Values are mean $\pm \mathrm{SD}$ (ranges). n: number of samples. nd: not determined

\begin{tabular}{|c|c|c|c|c|c|c|}
\hline Site & Morphotype & $\mathrm{n}$ & \multicolumn{2}{|c|}{$\begin{array}{l}\text { Relative abundance } \\
\% \text { of total }\end{array}$} & \multicolumn{2}{|c|}{$\begin{array}{c}\text { FVIC } \\
\% \text { of total }\end{array}$} \\
\hline East Sea & $\begin{array}{l}\text { Rod } \\
\text { Curved shape } \\
\text { Coccus } \\
\text { Spirillum }\end{array}$ & $\begin{array}{l}15 \\
15 \\
15 \\
15\end{array}$ & $\begin{aligned} 30.2 & \pm 5.9 \\
36.6 & \pm 6.0 \\
26.1 & \pm 3.5 \\
7.1 & \pm 3.7\end{aligned}$ & $\begin{array}{r}(17.6-38.6) \\
(27.7-52.0) \\
(20.2-31.1) \\
(2.6-16.4)\end{array}$ & $\begin{array}{r}0.4 \pm 0.2 \\
0.1 \pm 0.1 \\
0.7 \pm 0.3 \\
0.02 \pm 0.1\end{array}$ & $\begin{array}{r}(0-0.7) \\
(0-0.3) \\
(0.3-1.2) \\
(0-0.3)\end{array}$ \\
\hline $\begin{array}{l}\text { Oxic waters } \\
\text { in Masan Bay } \\
\text { (unpubl. data) }\end{array}$ & $\begin{array}{l}\text { Rod } \\
\text { Curved shape } \\
\text { Coccus } \\
\text { Spirillum }\end{array}$ & $\begin{array}{l}38 \\
38 \\
38 \\
18\end{array}$ & $\begin{array}{r}46.1 \pm 5.1 \\
33.4 \pm 5.7 \\
20.2 \pm 6.3 \\
0.8 \pm 0.9\end{array}$ & $\begin{array}{c}(32.9-55.5) \\
(23.3-44.9) \\
(5.5-30.7) \\
(0-3.5)\end{array}$ & $\begin{array}{l}0.4 \pm 0.4 \\
0.1 \pm 0.2 \\
0.4 \pm 0.3 \\
\text { nd }\end{array}$ & $\begin{array}{l}(0-2.6) \\
(0-0.5) \\
(0-1.1)\end{array}$ \\
\hline $\begin{array}{l}\text { Hypoxic waters } \\
\text { in Masan Bay } \\
\text { (unpubl. data) }\end{array}$ & $\begin{array}{l}\text { Rod } \\
\text { Curved shape } \\
\text { Coccus } \\
\text { Spirillum }\end{array}$ & $\begin{array}{r}14 \\
14 \\
14 \\
7\end{array}$ & $\begin{array}{r}46.2 \pm 4.1 \\
35.7 \pm 6.7 \\
17.6 \pm 5.8 \\
1 \pm 0.6\end{array}$ & $\begin{array}{c}(39.2-52.5) \\
(24.3-46.0) \\
(7.8-31.1) \\
(0-1.7)\end{array}$ & $\begin{array}{l}0.4 \pm 0.3 \\
0.2 \pm 0.1 \\
0.6 \pm 0.3 \\
\text { nd }\end{array}$ & $\begin{array}{l}(0-1.0) \\
(0-0.4) \\
(0-1.2)\end{array}$ \\
\hline $\begin{array}{l}\text { Weinbauer et al. } \\
\text { (1993) }\end{array}$ & $\begin{array}{l}\text { Rod } \\
\text { Coccus } \\
\text { Spirillum }\end{array}$ & & $\begin{array}{r}84.6 \pm 9.0 \\
10.3 \pm 8.1 \\
5.1 \pm 5.9\end{array}$ & & $\begin{array}{c}1.6 \pm 1.1 \\
5.1 \pm 3.6 \\
\text { nd }\end{array}$ & \\
\hline $\begin{array}{l}\text { Weinbauer \& } \\
\text { Peduzzi (1994) }\end{array}$ & $\begin{array}{l}\text { Rod } \\
\text { Coccus } \\
\text { Spirillum }\end{array}$ & $\begin{array}{l}53 \\
53 \\
53\end{array}$ & $\begin{array}{r}84.1 \\
10.7 \\
5.2\end{array}$ & $\begin{array}{r}(62.5-96.5) \\
(1.1-28.1) \\
(0-29.0)\end{array}$ & $\begin{array}{l}1.2 \\
2.5 \\
1.4\end{array}$ & $\begin{array}{l}(0-3.8) \\
(0-11.1) \\
(0-14.3)\end{array}$ \\
\hline
\end{tabular}

\section{An application of the model to field samples}

To test this idea, we measured $V P_{\text {TEM }}$ in seawater samples collected from the East Sea. Interestingly, the distribution of FVIC in each morphotype was not consistent with the relative distribution of morphotypes (Table 2). This trend was shown in other studies as well (references in Table 2). Cocci were more significantly infected than other morphotypes (ANOVA, p < 0.001). In addition, we examined whether growth rates would be different in each group by using the FDC (Hagström et al. 1979) of each morphotype as follows: First, bacterial community FDC was highly correlated

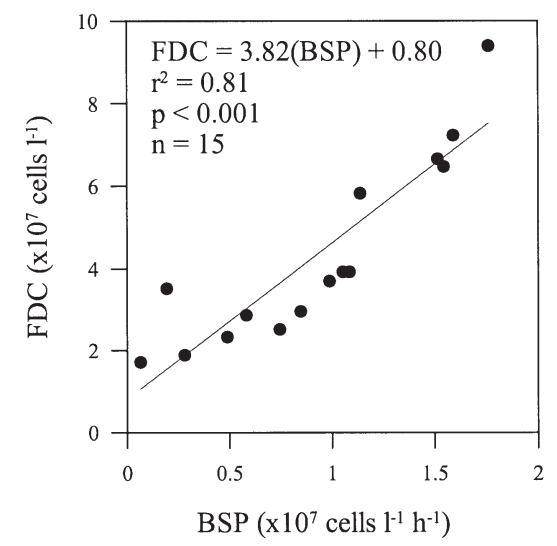

Fig. 2. Relationship between bacterial secondary production (BSP) and frequency of dividing cells (FDC) in the East Sea, 1999 with $B S P_{\mathrm{T}}$ (Fig. 2), suggesting that the FDC versus $B S P$ relationship for each morphotype would be similar to that for the bacterial community. Based on this observation, we converted FDC of each morphotype to the $B S P$ of each morphotype and then to the growth rate of the corresponding group by using the bacterial abundance of each group and an assumption of logarithmic growth in bacteria. In the East Sea, the mean growth rate of the bacterial community ranged from 0.01 to $0.08 \mathrm{~d}^{-1}$. However, growth rates in each morphotype were different from the community growth rate (cocci: 0.03 to $0.3 \mathrm{~d}^{-1}$, rods: 0.008 to $0.07 \mathrm{~d}^{-1}$, curved shapes: 0.007 to $0.05 \mathrm{~d}^{-1}$, spirillae: FDC was not detected), indicating uneven growth in each group (Fig. 3). From Eq. (13), we can proceed as follows:

$$
\begin{aligned}
& V P_{E(K)}=V P_{\mathrm{C}}+V P_{\mathrm{R}}+V P_{\mathrm{U}}+V P_{\mathrm{SP}} \\
& =Z_{\mathrm{C}} \times F I C_{\mathrm{C}} \times B S P_{\mathrm{C}}+Z_{\mathrm{R}} \times F I C_{\mathrm{R}} \times B S P_{\mathrm{R}} \\
& \quad+Z_{\mathrm{U}} \times F I C_{\mathrm{U}} \times B S P_{\mathrm{U}}+Z_{\mathrm{SP}} \times F I C_{\mathrm{SP}} \times B S P_{\mathrm{SP}}
\end{aligned}
$$

where subscripts $\mathrm{C}, \mathrm{R}, \mathrm{U}$ and SP represent, respectively, cocci, rods, curved shapes and spirillae for the corresponding variables. Applying both different values for growth and FVIC for each morphotype, we obtained a 1.2 to 2.8 times higher virus production $(n=$ 15) than those by conventional TEM approach. Given the facts that bacteria were only classified as 4 morphological groups and each morphotype would be expected to include bacteria with various ranges of growth rates, it was rather interesting that estimates of $V P_{E(K)}$ were greater than those of $V P_{E(1)}$. According to 


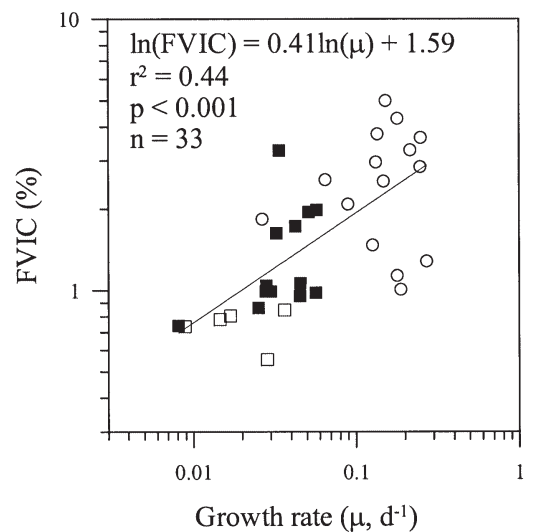

Fig. 3. A relationship between growth rate and frequency of visibly infected cells (FVIC) of bacterial morphotypes (O: Cocci; $\square$ : rods; $\square$ : curved shapes) in the East Sea, 1999

numerical simulations of our theoretical model (Fig. 1), such results (e.g. $V P_{E(K)} / V P_{E(1)}>1$ ) would be compatible with an assumption that fast-growing bacteria were highly infected.

Interestingly, growth rate and FVIC of bacterial morphotypes were significantly related (Fig. 3), confirming that fast-growing bacteria might be more infected by viruses and, thus, supporting our prediction of upward estimates of virus production. Recently, Thingstad (2000) suggested that difference in host growth rates is a crucial factor in the control of viral abundance. In his model, the high growth rate of a bacterial species is at a steady-state compensated by a high loss to viral lysis for this host. This would require a positive relation between growth rate and FVIC, and our result (Fig. 3) thus seems to support his hypothesis.

The increased estimates of virus production by our approach explicitly increase estimates of bacterial mortality due to viruses by 1.1 to 2.7 -fold and 1.1 to 3.0 -fold according to the models of Proctor et al. (1993) and Binder (1999), respectively. Thus, viruses might play a more significant role in bacterial mortality in aquatic environments than assessed by conventional TEM observation. Finally, it seems that uneven growth and susceptibility to viruses in bacterial community could be a partial explanation for the discrepancy between virus production measured by virus decay rates $\left(V P_{\mathrm{D}}\right)$ and $V P_{\text {TEM, }}$ in addition to adsorption of viruses to particles, degradation due to enzymes and inactivation caused by sunlight (Suttle \& Chen 1992, Fuhrman 1999).

Acknowledgements. We thank the captain and crew of RV 'Eardo', KORDI, for their excellent cooperation during the cruise. We thank Dr M. G. Weinbauer and 3 anonymous reviewers for valuable comments. We also thank $\mathrm{Mr} \mathrm{S}$. H. Nam for tutoring us on Fortran programs for numerical simulations of our models. This work was partly supported by the BK21 project of the Korean Government.

\section{LITERATURE CITED}

Binder B (1999) Reconsidering the relationship between virally induced bacterial mortality and frequency of infected cells. Aquat Microb Ecol 18:207-215

Cho BC, Na SC, Choi DH (2000) Active ingestion of fluorescently labeled bacteria by mesopelagic heterotrophic nanoflagellates in the East Sea, Korea. Mar Ecol Prog Ser 206:23-32

Ducklow HW, Kirchman DL, Quinby HL (1992) Bacterioplankton cell growth and macromolecular synthesis in seawater cultures during the North Atlantic spring phytoplankton bloom, May, 1999. Microb Ecol 24: 125-144

Fuhrman JA (1999) Marine viruses and their biogeochemical and ecological effects. Nature 399:541-548

Fuhrman JA, Noble RT (1995) Viruses and protists cause similar bacterial mortality in coastal seawater. Limnol Oceanogr 40:1236-1242

Gasol JM, del Giorgio PA, Massana R, Duarte CM (1995) Active versus inactive bacteria: size-dependence in a coastal marine plankton community. Mar Ecol Prog Ser 128:91-97

Guixa-Boixareu N, Calderón-Paz JI, Heldal M, Bratbak G, Pedrós-Alió C (1996) Viral lysis and bacterivory as prokaryotic loss factors along a salinity gradient. Aquat Microb Ecol 11:215-227

Hagström ̊̊, Larsson U, Höstedt P, Normark S (1979) Frequency of dividing cells, a new approach to the determination of bacterial growth rates in aquatic environments. Appl Environ Microbiol 37:805-812

Heldal M, Bratbak G (1991) Production and decay of viruses in aquatic environments. Mar Ecol Prog Ser 72:205-212

Microsoft Corp. (1994) Fortran PowerStation, release 4.0, Redmond, WA

Noble RT, Fuhrman JA (2000) Rapid virus production and removal as measured with fluorescently labeled viruses as tracers. Appl Environ Microbiol 66:3790-3797

Pinhassi J, Azam F, Hemphälä J, Long RA, Martinez J, Zweifel UL, Hagström $\AA$ (1999) Coupling between bacterioplankton species composition, population dynamics, and organic matter degradation. Aquat Microb Ecol 17: $13-26$

Pollard PC, Moriarty DJW (1984) Validity of the tritiated thymidine method for estimating bacterial growth rates: measurement of isotope dilution during DNA synthesis. Appl Environ Microbiol 48:1076-1083

Proctor LM, Okubo A, Fuhrman JA (1993) Calibrating estimates of phage-induced mortality in marine bacteria: ultrastructure studies of marine bacteriophage development from one-step growth experiments. Microb Ecol 25: 161-182

Simon M, Azam F (1989) Protein content and protein synthesis rates of planktonic marine bacteria. Mar Ecol Prog Ser 51:201-213

SPSS Inc. (1997) SPSS for Windows, release 8.0. SPSS Inc, Chicago, IL

Steward GF, Wikner J, Cochlan WP, Smith DC, Azam F (1992) Estimation of virus production in the sea: II. Field results. Mar Microb Food Webs 6:79-90

Steward GF, Smith DC, Azam F (1996) Abundance and production of bacteria and viruses in the Bering and Chukchi Seas. Mar Ecol Prog Ser 131:287-300

Suttle CA (1993) Enumeration and isolation of viruses. In: Kemp PF, Sherr BF, Sherr EB, Cole JJ (eds) Handbook of methods in aquatic microbial ecology. CRC Press, Boca Raton, FL, p 127-129 
Suttle CA, Chen F (1992) Mechanisms and rates of decay of marine viruses in seawater. Appl Environ Microbiol 58: 3271-3279

Thingstad TF (2000) Elements of a theory for the mechanisms controlling abundance, diversity, and biogeochemical role of lytic bacterial viruses in aquatic systems. Limnol Oceanogr 45:1320-1328

Turley C, Lochte K (1986) Diel changes in the specific growth rate and mean cell volume of natural bacterial communities in two different water masses in the Irish Sea. Microb Ecol 12:271-282

Editorial responsibility: Gunnar Bratbak,

Bergen, Norway
Weinbauer MG, Peduzzi P (1994) Frequency, size and distribution of bacteriophages in different marine bacterial morphotypes. Mar Ecol Prog Ser 108:11-20

Weinbauer MG, Suttle CA (1997) Comparison of epifluorescence and transmission electron microscopy for counting viruses in natural marine waters. Aquat Microb Ecol 13: 225-232

Weinbauer MG, Fuks D, Peduzzi P (1993) Distribution of viruses and dissolved DNA along a coastal trophic gradient in the Northern Adriatic Sea. Appl Environ Microbiol 59:4074-4082

Submitted: March 22, 2001; Accepted: December 7, 2001 Proofs received from author(s): March 18, 2001 